Revue d'études américaines. American Studies Journal

$2 \mid 2017$

(Hi)stories of American Women: Writings and Rewritings / Call and Answer: Dialoguing the American West in France

\title{
African American Womanhood: A Study of Women's Life Writings (1861-1910s)
}

\section{Élise Vallier}

\section{OpenEdition}

Journals

\section{Electronic version}

URL: https://journals.openedition.org/transatlantica/10220

DOI: 10.4000/transatlantica.10220

ISSN: $1765-2766$

Publisher

Association française d'Etudes Américaines (AFEA)

\section{Electronic reference}

Élise Vallier, "African American Womanhood: A Study of Women's Life Writings (1861-1910s)",

Transatlantica [Online], 2 | 2017, Online since 22 May 2019, connection on 31 January 2023. URL:

http://journals.openedition.org/transatlantica/10220 ; DOl: https://doi.org/10.4000/transatlantica. 10220

This text was automatically generated on 31 January 2023.

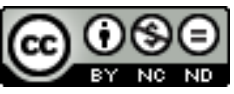

Creative Commons - Attribution-NonCommercial-NoDerivatives 4.0 International - CC BY-NC-ND 4.0 https://creativecommons.org/licenses/by-nc-nd/4.0/ 


\title{
African American Womanhood: A Study of Women's Life Writings (1861-1910s)
}

\author{
Élise Vallier
}

1 From 1861 to the late 1910s, the conditions of freedom and the national gendered and racial context forced African American women to rethink what it meant to be a woman. This is a complex period in American history in which two distinctive sub-periods emerged: from 1861 to the 1880s, and from the 1890s to 1920. During Reconstruction (1863-1877), African Americans obtained citizenship rights and a brief period of political empowerment opened for African American men. But this period of hope was short-lived: as W.E.B. Du Bois said, "The slaves went free; stood a brief moment in the sun; then moved back again toward slavery" (2013 26). Indeed, African Americans soon entered a period in which their economic, social and political circumstances were again increasingly threatened: 1877-1901 has been termed by the historian Rayford Logan the "nadir" in American race relations because it was characterized by extreme tension between black and white Americans. On an economic, political and social level, a more difficult period followed for African Americans. After the 1890s, the United States experienced a period of exacerbated racism-with the loss of African Americans' political rights and the Plessy v. Ferguson Supreme Court decision-and reaffirmation of woman's inferiority at the turn of the century.

In these contexts, most black women had to adopt ways of being women and citizens that were distinctive from their white counterparts' and not always in keeping with Victorianism as defined in the early nineteenth century. ${ }^{1}$ As Glenda Gilmore argues, "black women's concepts of woman's place were far from monolithic, but all were marked by the experience of exclusion and the challenge of meeting adversity" (32, emphasis mine). Like Joyce Ladner, I believe that "[t]here is no monolithic concept of the black woman [in America], but [...] there are many models of black womanhood" (271, emphasis mine). 


\section{Corpus}

3 In order to study these "many models" of black womanhood, I selected the writings of seven women. Five were born before the end of the Civil War and two after 1865, an important chronological boundary since being born before the Civil War-whether free or enslaved-or after 1865 had an impact on these women's prospects and on their expected roles as women. First, the southerner Elizabeth Hobbs Keckley (1818-1907) was born a slave in Virginia, the daughter of George Pleasant and Agnes Hobbs. She grew up with her mother, who taught her how to sew at an early age. At some point, she was given to her owner's son. In 1839, the victim of a white man's sexual assaults, she gave birth to a son, George. In 1852, she married James Keckley, a short-lived marriage. By that time, she had become a successful seamstress. In 1855, she purchased her and her sixteen-year-old son George's freedom at the very expensive cost of $\$ 1,200$, thanks to loans from her clientele. In 1861, her son died in the war and in the early 1860s, Keckley became Mary Todd Lincoln's designer. At 49, she penned her autobiography, Behind the Scenes, or, Thirty Years a Slave, and Four Years in the White House.

4 The next two writers are the only northern-born women of this study. The former, Rebecca Primus (1836-1932), from Hartford, Connecticut, was born into an uppermiddle-class family of color. From 1864 to 1869 , she served as a teacher to the contraband slaves in Royal Oak, Maryland, for the Hartford Freedmen's Aid Society, which funded her trip, before returning to Connecticut. Though successful in having a school built in Royal Oak in the 1860s, she left the South when the "Hartford Freedmen's Aid Society ceased operation [in 1869]" (Griffin 257). Sometime between 1872 and 1874, she married the southern-born Charles Thomas, whom she had met in Maryland. She then "kept home" and apparently never had children. The latter, Addie Brown (1841-1870), was a young domestic servant and seamstress born in Hartford, Connecticut, a long-time friend of Primus's with whom she maintained a ten-year love affair in the 1860s. Brown died in 1870, two years after getting married to Joseph Tines, a domestic worker.

5 The fourth woman in this study is a young diarist named Mary Virginia Montgomery (1849-1902) who was born in Davis Bend, Mississippi, into a successful black family. Her parents were former slaves who were offered to work on Davis Bend, the famous plantation owned by the Davis family. Her father, Benjamin T. Montgomery, was a talented slave, an inventor and machinist, while her mother, Mary Lewis Montgomery, was a slave. The couple belonged to Joseph Davis, Jefferson Davis's older brother. After taking refuge in Cincinnati during the Civil War, the family leased the Davis family's plantation. Mary was emancipated at fourteen and subsequently worked as a bookkeeper's assistant, while her mother was a field hand. A learned and accomplished young lady, Montgomery played the piano and read extensively (Sterling 466). She kept her diary in 1872, prior to leaving for Oberlin College, Ohio, where she trained to become a teacher. She subsequently went back to teach in Mississippi in $1874 .{ }^{2}$

6 The next case study deals with Ida B. Wells-Barnett (1862-1931), the famous journalist, clubwoman, lynching crusader and activist born in Yellow Springs, Mississippi. Her parents-who had been slaves-both died during the Memphis yellow fever epidemic of 1878 when she was a teenager. When she became the sole family provider, she worked as a schoolteacher in Tennessee public schools. Dissatisfied with her lot, she did all she could to work as a journalist in the mid-1880s and later became a famous activist in the 
crusade against lynching. ${ }^{3}$ She moved to Chicago after her marriage to Ferdinand Barnett, a famous black lawyer. She kept her diary in 1886-1887 and started writing her autobiography in $1928 .{ }^{4}$

7 The sixth woman in this study is Elizabeth Johnson Harris (1867-1942), born and raised in Augusta, Georgia, to parents who had been slaves. Her grand-parents were given a plot of land by their former owners (Harris 5). At 15, she married Jacob Walker Harris in 1883 and had nine children, seven of whom survived to adulthood. A housewife, she penned her memoir in 1923, Life Story, at the age of $55 .{ }^{5}$

The last case study is an anonymous woman "born and reared in the South" who was forty when she was interviewed by a reporter from The Independent, a white-owned weekly newspaper published in New York City between 1848 and 1921. At its beginnings, it was an important voice in support of abolitionism and woman's suffrage and it published articles by renowned African American activists such as Fannie Barrier Williams or W.E.B. Du Bois in the early twentieth century. Her life story entitled "'More Slavery at the South,' by a Negro Nurse" was published in 1912. Her account sheds light on the economic and living conditions of black women domestics in the South from the 1890 s to the early 1910 s.

9 The corpus presents a mix of similarities and differences: five women were Southerners while two, Brown and Primus, were born and lived in the North. Four belonged to the educated middle class, were geographically mobile, and traveled outside their native region, ${ }^{6}$ two of whom came back home: Primus returned to Hartford, Connecticut, and Montgomery returned to Mississippi after studying at Oberlin College. Three of them stayed in their native region-Harris and the anonymous child-nurse never left the South very long while Brown remained in the North. ${ }^{7}$ Two women-Keckley and Montgomery-were born in slavery, while Wells and Harris were the daughters of former slaves who had either been freed or who had bought their freedom. Two of them were born to free families of color in the North before the war-Primus and Brown. Lastly, three of them-Primus, Wells, Montgomery-worked as teachers at some point in their lives.

10 I selected these women because their accounts testify to the diversity in African American womanhood between 1861 and the early 1910s. Their personal testimonies are representative of distinct individual trajectories that, analyzed together, make out a collective history of African American women in the post-Civil War era.

11 This study covers a long historical period, from Reconstruction to the difficult 1910s and 1920s marked by Jim Crow laws. This was also an important time for women because 1920 saw the ratification of the Nineteenth Amendment, which finally gave American women the right to vote, after years of struggle. Between 1861 and 1920, how did African American women cope with the contradictory demands of dominant understandings of womanhood? What did womanhood mean for them? In what specific ways did they think about their working lives? How did they approach work? Obviously, they often viewed work as something that would support their families, but did they also value the idea of advancing a career, or a skill? How did their social circumstances impact their views of womanhood? Finally, how did this notion of "womanhood" among women of color evolve throughout the period? 


\section{Methodology}

12 In order to answer these questions, I use several forms of writings: diaries, autobiographies and correspondence. Diaries and letters often belong to what Margo Culley terms "writing of the instant" (Culley) while autobiographical writing belongs to the category of "a posteriori writing" (Miraux). Diaries - defined by the Oxford English Dictionary as "a book in which one keeps a daily records of events and experiences"offer twenty-first-century readers a window on nineteenth-century women's intimate thoughts and personal reflections. Both diarists of this study-Montgomery and Wellskept their diaries to themselves and did not seem to exert any self-censorship since they did not intend to publish their journal. For example, Wells's Memphis Diary was kept locked in a drawer and was therefore not written to be perused or published (McCurry 69). Secrecy, however, is a fraught notion. “Isn't the reader always here, after all?" (Didier 8). Because a diarist indeed often writes to himself or herself or to an imaginary friend, the diary is akin to correspondence. Moreover, because it often projects the diarist's thoughts soon after the event that is recounted, the diary offers an almost immediate impression of facts. Additionally, as the rhetoric scholar Kimberly Harrison explains, because the diary provided room for "rhetorical rehearsals" (Harrison), it was a place where women could express their personal and political voice. In the case of African American women diarists, the journal could be the place to express their personal feelings in the face of racial violence, intimidation, and discrimination, but also their political ideas and demands for civil rights for American Americans. Indeed, some black diarists could refer to difficult violent experiences, therefore expressing a certain degree of insecurity. As a result, journals kept by African American women differ greatly from those written by white women.

13 In the case of personal correspondence, the lapse of time between events and the time of writing is also often short. Moreover, the main purpose of writing to a friend, relative, or acquaintance is to provide news, speak about recent developments and/or share one's feelings and thoughts. Depending on the degree of intimacy between the two pen friends, the reader of personal letters is often able to peruse intimate details of the writer's life and thoughts. Here, Brown and Primus wrote each other frequently as they were very close and intimate. Their letters are immensely valuable because a good number of them are love letters. In them, Brown and Primus describe their love and their longing for their next moment together. No censorship was exerted because, as Farah Jasmine Griffin, the editor of the letters, explains, both women were "not concerned with publication or with a white audience. As such, their letters provide a rare glimpse into the day-to-day activities of two ordinary black women" (Griffin 4). Both diaries and letters-when they are not censored, which is the case here-offer insights into the intimate lives of women.

On the contrary, memoirs, reminiscences, and autobiographies are written with a readership in mind. Additionally, according to Philippe Lejeune, the autobiography is "a retrospective in prose which a real person makes of his or her own existence, when he or she places the emphasis on his or her individual life, in particular on the history of his or her personality" (Lejeune 14). While memoirs place the emphasis on historical events, external to the person, autobiographies and reminiscences reveal elements of the writer's private life and are centered on the self. The writings of Keckley, the "life story" of Elizabeth Johnson Harris, and Wells's autobiography belong to this genre. 
Wells and Harris, in particular, evoke their personal life, childhood, family, courtship, marriage, and role as mothers, as well as their children's achievements, but evoke few historical events.

Because autobiographical writings offer information on how the writer views events that occurred years or decades earlier, these a posteriori notes are informed by the passage of time and the context of publication has a major importance. Here, Harris wrote her life story in 1923, at the age of 56, while Wells wrote her diary in 1886-1887 when she was about 25 and her autobiography in 1928 at the age of 66: her stance is obviously different. Lastly, these writings also show how the author would like to be remembered. They enable the historian to learn "a great deal about the way an individual perceived him or herself and his or her times (if the witness's misrepresentation is honest) or about how the individual would like to be remembered", Wallach says of memoirs of the Jim Crow era (Wallach 31). The women's narratives studied here offer a unique insight into their thoughts and ideas. Highlighting and listening to their voices enables to explore their history in a fair manner that compensates the silencing and misrepresentation of black men and women after the Civil War. Whether in the press, literature, or on the radio, black minstrelsy depicted men as either silly, ridiculous, or immoral-the image of the black rapist was created during the Jim Crow era-while women of color were represented as either tragic mulattoes or lustful temptresses-Sapphires or Jezebels. Moreover, personal writings offer historians the opportunity to give these women their voices back-voices which, for a long time, remained unheard in American history-although it should be stressed that women of color who did not have the luxury of writing letters or diaries, did express themselves differently, for instance through singing, praying, quilting, story-telling, and cooking.

Through this portrait gallery, I hope to offer fresh insights on black womanhood between 1861 and 1920. Indeed, like John Stauffer, I believe that "only by changing perspectives, listening to multiple voices from different social groups and vantage points, is it possible to understand how racial identities get defined, blurred, and remade" (Stauffer 3). My goal here is therefore to analyze how these women-who came from different backgrounds and who had distinct family histories-depicted what dominant views of womanhood and notions or respectability and propriety in the United States meant for them within the African American society. I will show that despite their social, regional, and occupational differences, most women understood womanhood as an articulation of normative views and personal agency. I will also demonstrate that their visions of womanhood changed between 1861 and 1920. Lastly, I will show how they developed a dual womanhood that both conformed to and contravened the Victorian ethic. In the first part of this article, I will provide a brief historical perspective of black womanhood in America; then I will explain how these women insisted on the importance of being exemplars of morality, accomplishing community work, promoting education, and writing. In a third part, I will examine how these women's economic situations tinged their views on the institution of marriage and motherhood. 


\section{American Womanhood in Historical Perspective}

17 In the United States, black and white women were historically viewed as having distinct social functions and qualities. Let us first briefly discuss white womanhood and then study African American womanhood.

After having been important economic contributors to the American economy through their roles as productive housewives since colonial times, white American women gradually found themselves deprived of a sense of usefulness in the world outside home. Their social functions were indeed narrowed down with the Industrial Revolution. Their role began to revolve mainly around motherhood. This is what Sara Evans terms "maternal commonwealth" (Evans 119-143). Yet, this role was seen as socially meaningful because women's influence on children was thought to be critically important for the nation. Interestingly, the ideology of Republican motherhood "allowed women a kind of public role as mothers of future citizens" (Foner 347). A change occurred from the early 1820s, however, when the ideology of "Republican motherhood' was transformed into the cult of domesticity. With industrialization, white American women came to be exclusively viewed as procreators. Their place was thus in the home, the private sphere, while men invested the public sphere in an age of reinforced commercial exchanges.

Within this cult of "True Womanhood" premised on the theory of separate spheres, only middle-class white women could qualify as respectable. As Barbara Welter put it in a famous 1966 article and in Dimity Convictions, the four cardinal virtues of a true woman were: piety, purity, submissiveness and domesticity (Welter 152). Nineteenthcentury white women were expected to be observant of feminine attributes such as discretion, modesty, docility; they also had to show a self-effacing character. Yet, what was new was not the idea of true womanhood, but the fact that it was placed upon a pedestal. Paula Giddings makes it clear that "[ $[\mathrm{t}]$ he idea of the lady was not new of course. What had changed was the cult idea, its elevation to a status symbol" (Giddings 43).

20 In antebellum America, enslaved black women were not regarded as human or as women but as chattel. African American women were excluded from the definition of women (Carby, 1987 6; Perkins, 1983 183; Silber 13). ${ }^{8}$ Before 1865, in fact, the abolitionist and feminist movements were closely intertwined and several famous black female abolitionists such as Harriet Tubman and Sojourner Truth were defenders of women's rights. From the very beginning of their life in freedom, black women were not permitted to live by the same standards as white women. In the eyes of both northern and southern whites, the four cardinal Victorian attributes did not apply to women of color. Yet, contradictorily, pressure was exerted on women of color. If black women failed "to adhere to any of these tenets-which the overwhelming number of Black women could hardly live up to"-they were considered as "less than moral, 'true' wom[e]n" (Giddings 47). This exclusion lasted well after the Civil War. For Carby, "though the cult of true womanhood did not remain the dominant ideological code, it should be remembered that the exclusion of black women from dominant codes of morality continued throughout the century" (Carby, 1987 39; Gilmore 36).

21 After 1865, all African American women could for the first time finally express their womanhood in a context of legal freedom. During Reconstruction, when southern states were placed under the patronage of the federal government, women of color 
struggled to find their positions as women and had relative latitude in defining their femininity. After emancipation, the only freedom most African American women were given was indeed only legal since their economic and social liberty was infringed. Moreover, guidelines were given by both white Americans and African-Americans of the upper-class. Their ideas of femininity came in the wake of the ideology of cleanliness spread by schoolmarms and northern missionaries during Reconstruction, but they were also conveyed by the educated black elite who belonged to the pre-war free communities of both northern and southern urban centers, such as New York and Philadelphia, Charleston, and New Orleans. The conservative, Victorian definition of black womanhood the African American elite had crafted was tremendously transformed by women of color in America between 1865 and 1920. Most of them indeed had to keep embracing both the domestic sphere and that of work. Depending on their social circumstances, they could display at least two of the qualities of "piety and purity" laid out by the "Cult of True Womanhood," and were compelled to reject the other two demands of "domesticity and submissiveness". Many rejected attitudes of submissiveness, displayed their intelligence, and did not hesitate to overtly challenge their husbands or be outspoken.

Toward the end of the nineteenth century, elite African American women developed a "dual womanhood" in which they could "fulfill both the European-American and the African-American cultural expectations" (Carlson 70). Since members of the black and white middle-class generally failed to appreciate the distinct forms of resilience developed by former slaves, this specifically concerns middle-class women. They harmoniously displayed two apparently opposed types of qualities, leading to the figure of the "black Victoria," a paragon of femininity and virtue whose ideals were often unattainable to working-class women. ${ }^{9}$

23 At the turn of the twentieth century, a change occurred. American society was experiencing important changes and Victorianism was gradually losing ground-Sara Evans terms this "the breakdown of Victorianism." While white women confronted the ambient sexism, women of color had to continue building their identity in a context of increasing racism and sexism: the sexism they faced was fundamentally different from that which white women knew (Evans 160-161). The rise of a racist propaganda in the early twentieth century, the renewed theory of women's inferiority, and the combination of racism and sexism, added to eugenics, affected the way women-black women in particular-viewed womanhood (Perkins, 1983 187-188). How did women of color in America interpret womanhood in both periods? In other words, how did they receive, transmit, and/or reshape these norms for the following generations? In order to address these questions, I will now examine how these women defended their integrity and prized education to combat negative images.

\section{The Defense of Their Integrity}

Under slavery, negative stereotypes of black women were created in the form of the sexually impure and lascivious "Jezebel." In the late nineteenth century, the figure of the obsequious, subservient and asexual "Mammy" emerged in American popular fiction and minstrel shows developed dramatically at this time (Boggle; Cox). These stereotypes circulated in both the North and the South of the country. As a result, it was common among women of color-particularly among southern black women-to be 
concerned with defending the image of the black woman in both periods. From 1861 to the late 1910s, women acted on several levels in order to defend their image.

The first is the question of morality and purity, in a context where women in the late nineteenth century felt unprotected by men. Purity is a fraught term today, it was used by many elite African American women, be they journalists or authors of etiquette books for young black women and girls, such as Emma Azalia Hackley. They used "purity" to refer to virginity but it also implied the idea of maintaining a good reputation (Hackley). I will now explore the nature of these strategies.

If black women's need to be economically self-reliant affected their experience of motherhood, sexual exploitation by white male employers also endangered their purity and emphasized their vulnerable social position. In fact, as Carby explains, "the rape of black women in the South continued to be an institutionalized weapon of oppression after emancipation" (Carby, 1987 39). As under slavery, black women who worked as domestics after 1865 often suffered attacks by white employers and were unable to defend themselves. Indeed, through different violent methods, men of color were also often prevented from defending them, for instance, through institutional racism, intimidation by the $\mathrm{Ku}$ Klux Klan, threats of rape against women, etc. According to some women in this study, few men could help them protect their sexual integrity. It was particularly true for working-class women and orphans who had no immediate male relatives. For instance, when Ida B. Wells heard of rumors about her respectability, she insisted on defending herself alone. She explained in her autobiography that even friendly northerners could draw hasty conclusions about black women's honor. One day, she wrote, the wife of a Minister from Ohio who had accommodated her in Vicksburg, Mississippi, "had gotten a torn letter of [hers] out of the wastebasket in his home", thought that there "was showing that [she] had lost [her] position in Memphis and that [it] looked very suspicious. The conclusions he drew were to the effect that morally there were no virtuous southern girls" (Wells, 197043 ). Wells did not hesitate to go to the Minister's in order to confront him and his wife. She later wrote in her autobiography: "I told him that my good name was all that I had in the world, that I was bound to protect it from attack by those who felt that they could do so with impunity because I had no brother or father to protect it for me." (Wells, 1970 44, emphasis mine). The Minister's reaction is typical of northern missionaries of the American Missionary Association who came to educate and moralize newly emancipated slaves and were often prejudiced against black women due to the Jezebel stereotype (McPherson). Wells's comment reveals the importance of both EuroAmerican bourgeois values and the paramount importance of good name in African American culture. Conversely, on Davis Bend plantation in the 1870s, Mary Montgomery does not allude to her protection (or lack thereof). One may imagine that her brothers and the relative economic and social autarky in her town protected her from potential attacks. Additionally, Montgomery did not seem to go outside the plantation very often, even less so by herself.

Both before and after the Civil War, African American women could be victims of sexual abuse and, when unprotected by men, developed various strategies against it. One of these consisted in working in community associations and getting involved in voluntary work for the poor, aged, orphaned, and sick in order to help the community and to give a truer image of African American women. According to Darlene Hine, many women continued a tradition that had begun under slavery and their 
"benevolent actions had the added bonus of underscoring the moral and spiritual righteousness of African American women" at a time when it was under attack (Hine $65)$.

This persisted into the twentieth century. Implicit in the anonymous child-nurse's account of this period is the permanent feeling that men-be they black or whitefailed to protect women from sexual aggressions. Moreover, they faced the difficulty of raising children in a context of economic and sexual domination. Men's inability to defend women because of the violence of Jim Crow laws forced many women of African descent to continue a tradition of self-reliance in the post-emancipation period. By working outside their home, many African American women continued to be potentially exposed to sexual threats and they often felt they had to fend for themselves. What is more, after the myth of the black rapist was created after the Civil War, not only was lynching made socially acceptable to avenge white womanhood, but the crime of raping black women was rendered even more invisible (Davis 121-122). The myth of the black rapist reveals American constructions of manhood and womanhood, since the black rapist was seen as the sexual brute unable to resist white southern womanhood-always depicted as pure women, "ladies." In propagating of the idea of the Lost Cause, the film The Birth of a Nation (1915) popularized this myth (Guterl 12). More generally, men were construed as lacking sexual restraint, while black women were portrayed as immoral and indecent. Both myths in fact functioned together (Davis 127). In this regard, Ida B. Wells's writings point out that accusations of rape on white women were used to commit lynching and to deprive black males of their political rights and their manhood. This affected black women in that the rape of black women was of no consequence outside the black community, since "black women were relegated to a place outside the ideological construction of 'womanhood' since that term 'included only white women"' (Carby, 1986 309). For example, in the 1910s, as the anonymous child-nurse explained in her account, domestic workers continued to be potential victims of white men's lust. She explains how she lost her position after "shoving away" her white employer when he made her sexual advances while she was a young married woman. She writes that when she was young and newly married she "didn't know [...] that what [sic] has been a burden to [her] mind and heart ever since: that a colored woman's virtue in this part of the country has no protection" ("More Slavery at the South"' 196, emphasis mine). She does not only allude to white men, though: she denounces being "assailed by white men, and by black men, who should be our natural protectors" (“"More Slavery at the South"' 196).

No other women of this sample testified about such sexual behavior among black men in their writings, probably because of self-censorship or censorship. Moreover, it is interesting to note that she used the term "natural" protectors, implying that because of race, black men were to protect women of color, at a time when it was particularly difficult for working-class African Americans to appropriate bourgeois norms of matrimony and family life. Here, it appears that the anonymous child-nurse had a large readership in mind: she hoped to call black men's attention on the necessity to defend their women, and she wished to draw the attention of both blacks and whites on the abuse women were victims of by men of both races. Like Wells years before, she explains:

I confess that I believe it to be true that many of our colored girls are as eager as the white men are to encourage and maintain these improper relations; but where the girl is not willing, she has only herself to depend on for protection. If their fathers, 
brothers, or husbands seek to redress their wrongs, under our peculiar conditions, the guiltless negroes will be severely punished, if not killed, and the white blackleg

will go scot-free! (“"More Slavery at the South"' 196, emphasis mine)

Since she was writing in 1912, in the midst of the Great Migration-which saw many women of color fall prey to procurers in northern urban centers-she may have tried to counter her readers' belief that all African American women lacked morality. In addition, whereas white men very often remained unpunished, when her husband tried to speak with the employer, the latter called the police and her husband was fined \$25 for "lying". This punishment-which was both symbolic and predictable-shows the continuity between the punishments inflicted to black men under slavery and those inflicted during the Jim Crow era.

Denouncing the injustice of the situation, the child-nurse also reveals that black women had to construe womanhood very differently from white women, even more so after the 1890s, when the myth of the black rapist was created. This was also the time when the Jezebel became a popular stereotype at that time, partly to account for the relative failure of missionaries who had worked during Reconstruction to moralize freedmen and freedwomen. The image was also used to justify black men's disenfranchisement. In 1912, at the height of the Jim Crow Era, black men who defended their wives or daughters from sexual aggressions often, with reason, feared retaliation by southern whites, as lynching was used as a threat to maintain blacks in a subordinate condition. Consequently, black women directly and indirectly suffered from this situation: institutional racial and gender subordination therefore forced these women to be more independent, sometimes at the risk of losing their jobs or enduring financial penalties.

31 In both periods (before and after 1900), sexual exploitation by white male employers endangered women's physical integrity and emphasized their vulnerable social position. Yet African American women-leaders, in particular-continued to fight against such situations by defending the image of women of color. According to Hine, black women leaders "believed that part of the overall struggle for true racial advancement depended upon the extent to which [women] obliterated all negative sexual images of themselves" (Hine 12). The role of defending the image of women of color was played by elite black female activists and journalists such as Josephine St. Pierre Ruffin, Mary Church Terrell and Fannie Barrier Williams as of the early 1890s. Social class-and the class prejudice of members of the black elite-played an important part in this defense (Higginbotham). This form of self-defense was to play an important role in these women's sense of self-worth as it helped them restore their self-image in spite of external attacks.

\section{Girls' Strict Upbringing}

Whenever they could, women of color throughout the period adopted strategies to contradict stereotypes, but class influenced their realities. Women from humble backgrounds had a harder time maintaining "purity" in their workplace and sometimes in their private sphere and members of the middle- and upper-class could more easily protect their daughters. Yet, African American women very often did everything they could to raise their daughters in a strict fashion, in order to instill in them a sense of responsibility, respectability, purity and morality (Shaw; McPherson). 

comply with the Victorian code of conduct and girls were reared to become future race leaders (Shaw). They were raised with the sense that their mission was to promote race uplift and "were prepared not just for work but for professional positions, activism, and leadership roles" (Shaw 16). They were expected to become teachers, nurses, and educated mothers, or activists and journalists. Although women were denied civil rights, education was key to being race leaders. Because they had had the opportunity to be educated in schools founded by northern missionaries during Reconstruction, such as Spelman Seminary-for girls-or Howard University, members of the black middle class were intent on educating less privileged members of their race. Booker T. Washington, head of the Tuskegee Institute, insisted upon values such as education, morality, and thrift. In seeking to instill in their daughters a sense of self-worth and respectability, black middle-class families viewed Victorian ideals as complementary with race work or public sphere work. For example, when women of color got involved in the Temperance Movement, they at once promoted their own public image and fought for men's rights. It is clear that the southern-born Ida B. Wells's ideals of femininity were influenced by Victorianism. As DeCosta-Willis, the editor of her diary explains, "[h]er characterization of [her teacher] Miss Atkinson owes much to the ideology of puritanical Victorianism, propagated by white missionary teachers at Rust University" (Wells, 1995 76). A middle-class woman, Wells had been sensitized to Victorian ideals at a very early age. At Rust University, her schoolfellow Annie was the Professor's favorite because she had an obedient and "docile disposition" (Wells, 1995 78). Rust College was a historically black college founded in 1866 by the Freedmen's Aid Society of the Methodist Episcopal Church and related to the United Methodist Church. It was administered by whites when Wells attended. "Annie was the favorite, not because of her color (because others were fairer) and not because of her high intellectual powers, but because of her obedient disposition, her extreme tractableness, and therefore easily controlled and her evident ladylike refinement" (Wells, 1995 78). The question of docility was precisely one of the causes of tension between the two charismatic leaders -Booker T. Washington and Du Bois-and women of color were not immune to this tension. Several these women's writings reveal that they were grappling with the double bind of being docile and assertive at the same time. What is more, women of color could not expect white women of similar socio-cultural backgrounds to show understanding.

Wells often wrote about her failing to live up to the standards of Victorian perfection. For instance, she claimed to be "tempestuous, rebellious," "temperamental," and have a "hard headed willfulness", and she regretted "the trouble [she] gave, [as well as her] disposition to question authority" (Wells, 1995 78). Conversely, Miss Atkinson seemed to possess all of these qualities and Wells deeply admired her for this. In Wells's mind, Atkinson was "so fair and pure, so divinely good, [...] so thoroughly pleasant, so bubbling over with an effervescence of youth, health, high spirits, cheerfulness [...] that everyone is charmed without knowing why" (Wells, 1995 78).

The pressure of Victorian expectations at school or at home could indeed be strong middle- and upper-class girls. Interestingly, Wells would later be considered as the perfect embodiment of this dual noble back womanhood. She was "commended both 
for traditional 'feminine' qualities and for her intellect and service to the black community" (Carlson 68). Wells had therefore managed to conform superficially to Victorian norms while remaining faithful to her personality, needs, and aspirations.

According to Shaw, black girls of the middle- and upper-class South had to possess certain qualities such as "cleanliness, politeness, respectability and thriftiness" (Shaw 18-19). They learned how to "shop economically, eat sensibly, dress tastefully, keep their good reputation clean, show good character, control oneself, display self-reliance and maturity". In one word, they had to display "moderation in all" (Shaw 18-19). Possessing these qualities would ensure their social success-that is, being able to help less-privileged members of the community, becoming a teacher, a nurse, or a Minister's wife. This definition was socially and regionally dependent, since opportunities were more restricted in the South, with de jure segregation, than in the North, though de facto segregation did exist, but still offered women greater opportunities. The qualities sought in a woman differed among black and white women. Gilmore explains that "the prevailing image of middle and upper class white southern womanhood in the postbellum period devalued scholarship and outspokenness among young women" whereas "African Americans of both sexes entered Reconstruction valuing strength, initiative, and practicality among black women" (Gilmore 36). Subjected to these dual imperatives, girls had to find or be provided with guidelines. Parents or teachers of African American girls-who were not necessarily women or African American themselves-deployed a lot of energy in trying to model girls' character because they thought that the uplift of the race was at stake.

Parents and educators thought that African American girls of "the better class" represented their families and, by extension, "the race" (Shaw 17). Women of all classes were trained to be living examples and therefore internalized the norms for the sake of the group. Girls often felt the pressure exerted upon them and reproached themselves for not being sufficiently thrifty or not displaying a sufficiently agreeable character. For instance, Wells often felt bad about having difficulties balancing her budget or controlling her temper (Wells, 1995 138; 88).

In addition, women continued an Early Republic tradition of defending the respectability of the wider community of African American women. They viewed their womanhood as encompassing all other black women's. Wells discussed these themes in several of her articles of the 1880s and later on, in her memoir:

Virtue was not at all a matter of the section in which one lived; that many a slave woman had fought and died rather than yield to the pressure and temptations to which she was subjected. I had heard many tales of such and I wanted him to know at least one southern girl, born and bred, who had tried to keep herself spotless and morally clean as my slave mother had taught me. (Wells, 1970 44).

By emphasizing the fact that, while a victim of bondage, her mother had always been a moral woman, Wells deconstructs the link between slavery and sexual promiscuity and immorality-a theme American abolitionists had largely dwelled upon (McPherson; Kaiser-Farmer). She "felt that [she] had vindicated the honor of many southern girls who had been traduced by lying tongues" (Wells, 197045 ). Wells insisted on defending the whole of southern womanhood, regardless of class. To her, an "important question" that deserved to be addressed in her writings was southern women's respectability (Wells, 1970 42). That is what she sought to do as a journalist, using her background and her education to make her voice heard by both black and white Americans. Writing about women of color and American society without any filter was a weapon few 
women of color had at that time. Wells was aware of the powerful weight her voice could have after Emancipation, at a time when black women enjoyed as little protection as under slavery but did not receive the degree of sympathy their slave foremothers did.

\section{Being Exemplars of Virtue and Morality: Preventing Teen Sex and Early Pregnancies}

Some women wrote of constantly proving their self-worth, their morality and "purity" to both black and white America. Many were conscious of this social pressure when growing up.

41 Shaw demonstrated that "family standards of respectable behavior also included Victorian ideals of restraint regarding matters of female sexuality": restraint from sexual relations before marriage or out of wedlock that could endanger their careers by preventing them from entering educational institutions necessary to achieve social work (Shaw 23). In the 1860s, women of color were conscious of the stigma of any faux pas. They were also critical of those who ran the gauntlet. For middle- or upper-class women, pregnancy before marriage also meant risking one's future career. Though this was also true for white southern women, the consequences were more tragic for blacks, since their career prospects were more limited. In a letter to Rebecca, Addie Brown ironically commented on a black northern teacher coming back from the South: "Her health was miserable so her Mother sent for her to come home. Since her return, she present[ed] her Mother with a grand child. That is a new method of teaching" (Griffin 179). Yet, when one of her friends named Emily came back home pregnant, Addie wrote to Rebecca: "My Dear you must not be too hard on [Emily]. You must remember how they regard such things and just think for a moment how the girls act here. They don't seem to have no shame here" (Griffin 145). The two women commented on such events knowing that they would never find themselves in such predicaments. Interestingly, here, Addie sympathizes with the young servant. Moreover, as the editor explains, her words suggest that she is "slightly critical of Rebecca's regional biases" (Griffin 144). As sexual relations out of wedlock were looked down upon by both men and women, middle-class black parents were very careful that their daughters retained unsullied reputations and many black southern families preferred having their daughters marry light-skinned men and discouraged suitors who were considered too dark-skinned. In the early 1880s, when young Elizabeth Johnson was courted by the man who would become her husband, her grand-parents were very much concerned about respecting propriety and protecting their grand-daughter's respectability. Harris explains the watchful supervision she underwent at that time:

I happened to be well trained so as to keep myself in place, and never rushing out of my place, therefore though as a child, I continued to love-and with the right control of mind I kept my love-and myself in the proper place for a child. [...] But I had to be excused as I was not yet receiving young men company [sic], and I was compelled and willing to abide by the rules of my dear Grandparents regardless of the love on either side. (Harris 15)

At age 10, she exerted self-control when the man in question asked her if he could write her letters. She refused to "slip notes or letters" and informed her suitor that he would have to wait for her grandparents' permission. Seeing that she was "determined not to break the rules of the old folks or the peace in [her] simple but happy home", her suitor 
complimented her and accepted to abide by the rules of her family (Harris 15). When she was thirteen, her grandparents continued to keep a watchful eye on her. When her suitor "made the second call", her grandfather asked him to wait a "while longer", as she was young "and only a school-girl". The man agreed to "wait until consent was given by the old folks. After [that, they] corresponded for one year and eleven months before [being] married (16). Harris's explanation suggests that her family prized education very much, knowing that it was of paramount importance for her future. Harris's family seem to have considered two elements for their consent. First, they appeared to think that fifteen years old was an appropriate age to marry; second, they thought that, in this case, the courtship period had been sufficiently long and the suitor had proved serious enough and respectful of their authority for them to consent to the marriage. Harris details their activities during her suitor's visits: her grandfather would tell "slave and ghost stories" or all four would sing while she played music. The lovers were never left alone and adult supervision was mandatory (16-17).

Moreover, when they corresponded Elizabeth's grandparents insisted upon reading all letters exchanged (16). To northern and urbanized readers of the Independent who might consider such supervision drastic, she explains: "we knew that the future would bring around a change. So we very willingly and patiently abiding by their rules until by marriage vows, the glorious changes were made and all were well and satisfied" (17). It seems that Harris attributed this strictness to the generational gap between her and her grand-parents. Additionally, at the time she penned these lines, in 1923, she was visibly trying to defend these rules-reminiscent of slave culture, which was then looked down upon as backwards by African Americans who had migrated north and adopted new codes of conduct. She willingly abided by her grand-parents' strict rules, having seemingly understood that this was aimed at protecting her reputation and respectability. Although white women too were chaperoned, the preservation of a black girl's reputation was all the more vital. Quite unusually, Harris's testimony shows that she discussed such questions with her kin and that trust and communication were important values in the family.

43 After the 1890s, an early pregnancy still endangered the reputation of women of all social classes and very often complicated a working-class woman's life. When she became a mother, Harris was quite present for her children. She believed it was her duty to advise them and warn them about the risk of making ill choices. She thought "there is always room for advice from the parents" (23). Interestingly, Harris did so without making any difference between her children on account of their gender and did provide her daughters with additional, specific recommendations.

In addition to being dutiful representatives of the race and of exemplars of respectability, young African American women were expected to get an education whenever necessary. Their parents viewed education as the most important lever for their daughters and, by extension, for the race.

\section{Strategies: Education and Race "Uplift"}

All the women in this study highly valued education. For instance, between 1866 and 1868, Brown made great efforts at reading the press and novels in order to better her writing. The editor notes that Addie "seems to read more books than her more educated friend" (Griffin 79) and that her attempts were unusual for a woman of her 
class: "her letters defy the stereotypes of black domestics" (Griffin 79). Similarly, Mary Virginia Montgomery's diary shows that this young woman, who aspired to a career as a teacher, read a lot. In her diary, she noted reading numerous books such as Plutarch or Darwin's Origin of the Species or historical books (Sterling 466). She wanted to complete her studies at Oberlin College and her parents were both willing and able to assent to her wish (Sterling 468). Wells also strongly valued her education and that of her siblings. When she was in her twenties, she confided in her diary regretting not having studied more at Rust University when she was younger: "There is nothing I lament more than the wasted opportunities as I do my neglect to pick up the crumbs of knowledge that were within my reach. Consequently I find myself at this age as deficient in a comprehensive knowledge as the veriest school-girl just entering the higher course. I heartily deplore the neglect" (Wells, 1995 151). As a result, Wells took courses in 1887 in order to complete her education. Valuing education more than anything else, Harris also prized professional achievements. Additionally, Johnson writes in her Life Story that she wanted her children, regardless of gender, to study as much as they could: "[m]y girls and boys are all willing and honest workers, which is not a disgraceful move for poor persons, but I would feel so proud if they had only finished or gone higher in school" (Harris 18). That reservation notwithstanding, she rejoiced over their personal and professional achievements several times in her account (Harris 35).

In the 1890s, white middle-class women approached education differently from black women. Women had different purposes in getting an education: while university was a way for white women to get an education, reinforce their homemakers' skills, and find a husband, for black women, it was mainly a way to obtain a position as an educator (Perkins, 1983 183; Gilmore 43; Carlson 63). Whereas whites were often concerned that too much education would "unsex" women (Carlson 62), such fears did not affect women of color since they were denied attributes of Victorian femininity and respectability, especially through the Sapphire stereotype. Black and white women's higher education experience in the 1890s also differed because white women mostly went to single-sex institutions, whereas black women tended to attend historically black colleges and universities (HBCU), which were coeducational (Gilmore 36). White women then followed a separate curriculum and often married late-if at all-because of this single-sex rule, while black women often met their future husbands in the course of their studies. Anna Julia Cooper, for instance, met her husband when studying at Saint Augustine College in North Carolina. However, this was not the case for all seven women of this sample.

Most black men supported female education. Perhaps because African American men had always been aware that, if educated, black women could aid the whole community, they had supported female education before the war. Moreover, in a context of male disenfranchisement and educational opportunities for the community-through universities such as Howard or vocational colleges such as Tuskegee-men were convinced that women had a role to play, not only for race uplift, but also to reenfranchise African Americans. For instance, "black historian William T. Alexander was critical of the non-academic education offered by some contemporary schools for girls and women". He wrote:

Our miscalled education looks chiefly as to how a young woman may make a good

figure in society [...]. We see many who are afraid of saying openly when they think 
or feel, if it be in a position to the accredited opinion of the world. [...] We want men and women who will think for themselves (Alexander 595).

Like W.E.B. Du Bois, Alexander strongly believed that women should be offered the same possibility to educate themselves as men. Yet in the late nineteenth century, some black men came to see intelligent women as potential threats and were more hesitant about women's education. Indeed, in the 1870s and 1880s, "[a]s black men sought to obtain education and positions similar to that of white men in society, many adopted the prevailing notion of white society, of the natural subordination of women" (Perkins, 1983 187). Of course, at the same time, many middle- and upper-class fathers promoted education for their daughters and sent them to colleges and normal schools, in order for them to be able to obtain professional alternatives to domestic work where women suffered from sexual exploitation.

After the 1890s, many black men still had expectations for black women that differed from those white men had for white women. As Gilmore explains, black men could advocate "a version of separate spheres for African-American women and men", in accordance with the prescriptive literature and white northern teachers. They did not advocate the "cult of southern ladyhood" but "rather an evangelically driven ethos of 'usefulness'. Pursuit of 'usefulness' gave women a middle space between the spheres into which they might venture on the business of the race" (Gilmore 36). In short, since proving "useful" to the race did not contradict Victorian codes of conduct, black men chose to put the emphasis on usefulness rather than ladylike behavior. At the turn of the century, driven by their aspirations to serve in the Army and be re-enfranchised, many men of color kept supporting women's emancipation.

African American women of all classes had a legacy of community work. Well before the end of the Civil War, black women achieved community work for their "race". In fact, they were the forerunners of female community work in the United States. Women either became race workers because they were strong Christian believers or because they believed that education could solve African Americans' problems. For example, although Mary Montgomery had been raised in an anticlerical family-this was quite unusual in the United States - she became a Christian at the age of 23 when she attended Oberlin College, a Presbyterian school, where her family had sent her on account of its excellent academic reputation. As a non-Christian, she did not do any Church community work when she was young but when she was first exposed to Christianity, she expressed a genuine interest and wish to further her religious education (Sterling 471). Additionally, like several other women in this study, Montgomery deeply wished to become a teacher. On 5 September 1872, she confides in her diary: "Told Papa and Ma of my intentions. They assent to my wishes. Another light beams upon my future. Hope beats high" (Sterling 468).

Moreover, this role was expected of women. According to Perkins, "[i]t was expected that blacks who were able to assist, i.e. "uplift", other members of their race, would do so" (Perkins, 1981 332) and "race uplift was the expected objective of all educated blacks; however, after the Civil War, the implementation of this philosophy was placed primarily on the shoulders of black women" (Perkins, 1983 186, emphasis hers). Additionally, black women were seen as the "nurturers and guardians of-not the thinkers or leaders of the race" and "most black women educators accepted that charge" (Perkins, 1983 187). The women of this sample embraced this tradition of uplift. For example, Keckley's deep awareness of her belonging to the race prompted her will to create the Contraband Relief Association of Washington in 1862. Northern 
upper-middle-class Primus strongly wished to accomplish race work in the South because she felt it was her duty to help the wider African American community and since teaching was an acceptable position for a woman of her section and class, her family agreed to send her to Maryland (Griffin 10). Similarly, Montgomery returned to Mound Bayou as a teacher in 1874 and taught in a black school in Mississippi most of her life. Moreover, Primus was very active in her community throughout her life, although in a different way: after accomplishing her work as a teacher to the newly emancipated slaves of Maryland between 1866 and 1869, she remained constantly involved with her church and local Sunday school, where she taught more than forty years (Griffin 9, 283). Wells's calling was of a different nature: driven by a desire to express her political voice, she wanted to work as a journalist in order to defend the rights of the black community. Moreover, being active in religious associations or working as teachers was considered compatible with Victorian ideals among African American women. Even before slavery was outlawed, black families often did not view Victorian ideals as incompatible with race work or public sphere work. On the contrary, they understood them as complementary. As a result, many black women used their education and their family's values-hard work and selflessness-to be economically independent, and, whenever they could, serve the community. In addition, the racial and economic climate forced many women to keep working outside of home. For humble women, working was essential.

\section{Economically Independent Women}

51 In both periods studied here, African American women often were financially independent, either by choice or by necessity. After 1865, African American women's economic circumstances were influenced by the heritage of the "peculiar institution". Despite their inclinations, African American women, whether they had been enslaved or not, had to deal with the legacy of servitude. The negative legacy of bondage shaped the contours of post-war African American womanhood because, even after emancipation, "[t]he basic economic inequities and racial discrimination in all walks of life prevented the majority of the black population from entering the mainstream and competing in an open society" (Ladner 284). Both in the North and in the South, racial discrimination barred black women's access to most occupations and thus reduced their economic and social opportunities.

With emancipation, freedwomen were able to experience their womanhood in a new fashion. They were faced with the task of defining and asserting their own definition of womanhood in a predominantly white society, at a time when agents of the Freedmen's Bureau were present in the South. Agents encouraged black women to adopt feminine attitudes and attempted to make freedmen and freedwomen adhere to the mores of the larger (i.e. white Christian) society. Whereas black slaves had not been allowed to marry legally and none of their unions were legally recognized as after the war, Freedmen's Bureau agents encouraged marriage among ex-slaves to make sure freed women lived in legal Christian matrimony. Moreover, since slavery was condemned as morally wrong, agents aimed at moralizing the South. They also pressed the women to be obedient to their husbands (Kaiser-Farmer 12). In addition, black southern men insisted upon their wives abiding by Victorian rules and withdrawing from the fields (Evans 120-121; Kaiser-Farmer 170). Yet, because their landless sharecroppers' low 
wages kept most men from becoming their families' sole providers, women were to work as well to provide the family with sufficient income. Racial discrimination indeed placed black families in a situation of financial dependency. Consequently, freedwomen were to fulfil double chores-take care of their homes and children, and work outside (Kaiser-Farmer 15)-and soon felt overwhelmed. The attempts by the Freedmen's Bureau at instilling black women with Victorian codes of behavior were a failure because despite black or white men's insistence upon women keeping their "proper place," their economic situation did not allow them to conform. Moreover, many black women resisted Victorian gendered values because they "were not ready to accept a new form of domination in their new life in freedom" (Kaiser-Farmer 34).

The women in this study grew up when Victorian discourse on womanhood flourished, but in social environments where women were encouraged and expected to work as hard as men, on the fields or elsewhere. Two women in our sample were housewives: after marriage, Primus appeared as "at home" in the 1870 Hartford census (Griffin 281). Similarly, Harris was a housewife from the 1860s and did not refer to paid work outside of home. Many women in this study wished or had to assert themselves and be selfreliant. For example, Keckley started her own sewing business in Washington, DC, in 1860 with the help of women friends and she later relied on herself for her business (Keckley 64-65). When she wrote her account, she had been separated from her husband for years. Brown also had to depend upon herself as a young unmarried woman. She experienced difficult times as a domestic in Hartford and New York City in the 1860s. Several times, she complained to her friend Rebecca about late payment, scant salary, and long hours. For instance, on 16 April 1861, she recounted an argument that she had with "Mother" (her employer) because she could not pay her (Griffin 34). Brown was often dissatisfied with her financial and professional situation and was sometimes depressed. On another occasion, on 30 January 1862, she regretted having come to New York City and working for "Mother": "I was completely wore out [sic] for I had to take the bulk of the work I'm almost sick I do not mean bodily sickness Mother has not any work and father business [sic] is very dull. $\mathrm{M}$ is sometimes so disagreeable there is no living with her I often wish that I never come to NY" (Griffin 58, punctuation missing in original). In the 1880 s, Wells was economically independent as well, since she worked in primary schools. Teaching was a socially acceptable profession for women at the time and one of the few options for educated women of color (Gilmore 36). In 1870s Mississippi, Montgomery was active as well: she secured a position as a bookkeeper thanks to her family network.

Little change occurred in the decades after 1890: many women of color were either the only bread-winners of their households or contributed to the family income alongside their husbands. Proportionately more black than white women were involved in paid work, according to a study by W.E.B. Du Bois. As Perkins has pointed out, "[t]his disproportionate ratio is no doubt a reflection of the economic necessity of black women to their families" (Perkins, 1983 185).

The child-nurse explains in 1912 that she was the sole provider to her family: as a widow, she raised her three children on her own earnings. She was paid "[t]he pitiful sum of ten dollars a month for "this work-this lifetime bondage! [...] With this money I'm expected to pay my house rent, which is four dollars per month, for a little house of two rooms, just big enough to turn around in; and I'm expected, also, to feed and clothe myself and three children" (“"More Slavery at the South"' 196). Although she was not 
only economically but also psychologically independent, she did not choose to: being left a widow at age 25 after five years of marriage, she was compelled to fend for herself (196).

\section{Women's Views on Marriage, Men, Love and Motherhood}

For all their emotional and financial independence, many of these women wished to marry and have children. Except for Montgomery, for whom not enough information is available, all did get married at some point. Some were inclined to enter into matrimony quite early in their lives. For instance, Harris, raised in a stable landed family in a rural area and married to a man she describes as "an ordinary laboring man," naturally wished to start a family in the early 1880s. As a landowner, her husband worked while she remained home taking care of her children. In her autobiography, she explains that he had "always provided satisfactorily for the home and his family and through his general affection, kind heart, and peaceful manners, he made things pleasant for the home. He was always cheerful, youthful in his manner and actions, fond of music" (Harris 43-44). She could choose to stay at home and raise her children. As to housekeeping chores, while she liked cleaning and sewing and "arranging things about the house" (Harris 4), she never "cared much for [cooking]" (Harris 3). While she believed that a woman had to take care of her home, she saw a woman's work at home as an endless task: "according to the old adage, 'Woman's work is never done, from the rising to the setting of a glorious sun"' (Harris 3). Despite her modest background, her landed grandparents and her husband offered her financial security. As her husband could make a decent living in Georgia on their land from the 1870s through the 1910s, she did not consider working outside of home the way other women in this study had to. Men's financial solvability as well as their social status influenced African American women's attitudes toward marriage. Similarly, the anonymous child-nurse got married in her early twenties, while others, such as Keckley, Brown, and Wells, thought about marriage in their late twenties or early thirties. Keckley got married at 34, Brown at 27, and Wells at 33. Others considered marriage even later. For instance, Primus wedded between 1872 and 1874, between the ages of 36 and 38 .

For different reasons, some women did not rely either emotionally or financially on men. Former enslaved women had ambivalent feelings toward the institution of marriage because of past experiences under bondage. During slavery, male slaves were very often unable to fulfill their roles as protectors to their families. If they decided to defend their wives or mothers, the immediate effect could be physical punishment. Joyce Ladner explains that "this severe punishment is a reflection of the problems black men encountered when trying to exercise their rights and obligations to their families" (Ladner 281). This led some women to reject marriage. For instance, Keckley chose celibacy after her first experience of marriage. As a slave, she was repeatedly abused by her white master for four years and had an undesired child as a result (Keckley 39). In addition, she depicted her former marriage to an African American man as a disaster. She later "learned that he was a slave instead of a free man, as he represented himself to be" (Keckley 50). She confessed that "Mr. Keckley [...] proved dissipated, and a burden instead of a helpmate" (Keckley 50). Feeling deceived and 
betrayed, she focused on work and did not seek the company of men. Other women envisioned marriage only as a way to acquire economic and social security. For example, Brown's unstable financial situation led her to view marriage as the answer to her dissatisfaction. She wrote to her longtime friend and lover Primus: "neither romance no[r] love comes before the desire for economic and emotional security" (Griffin 60). Uneducated, from modest backgrounds, the young and still single Brown had no choice but to become a domestic and to make a living on her own, a common situation from the late nineteenth century to the 1950s (Gilmore 36).

Others regarded matrimony as an unenviable position for different reasons: they were not ready to start a family by the age of 25 , which was thought appropriate by society, or they wished to focus on their professional activity. For example, when she was 24 , on 15 June 1886, Wells wrote: "I am an anomaly to myself as well as to others. I do not wish to be married but I do wish for the society of the gentlemen." (Wells, 1995 80). In 1886 and 1887, she had several suitors yet she often wrote that she hoped they did not expect to marry her (Wells, 1995 116). Middle-class women's ambivalence to men and marriage can be explained by their wish to build a professional career. Wells did not wish to work as a public-school teacher her entire life: she wanted to become a journalist (Wells, 1995 111). As a result, getting married would have been a brake to her intended career.

Choices like postponing or avoiding marriage, living freely and being outspoken exposed these women to criticism from both black and white men. Their freedom sometimes triggered virulent reactions. Miriam DeCosta-Willis wrote that Wells "paid a high price-isolation, criticism and calumny [...]-for her failure to comply with social expectations for women of her class." In addition to class, Wells's attitude challenged the codes of her race and region-the conservative South: "By age twenty-four, she should have been married, like other female teachers [...] and [should have] had a child on the way. Since she was not, she became the object of vicious rumors". These were diverse: it was said that "she was involved with a White Holly Springs man 'for money, that she and a male teacher were 'immoral' and that she had had an illegitimate child" (Wells, 1995 114). When several males accused her of being "a heartless flirt", she wrote: "I have been so long misrepresented that I begin to rebel" (Wells, 1995 114). Wells later changed her mind about marriage, espousing Ferdinand Barnett in 1895, at the age of 33 and the Barnetts envisaged their marriage as a partnership.

Some women also viewed matrimony in a different light because of their sexual orientation, like Rebecca Primus and Addie Brown. Accounts of homosexual love in black and white women's writings are rare yet testify to the difficulty of coping with the social pressure to find a husband. In the 1860s and 1870s, upper-middle-class Rebecca Primus and working-class Addie Brown had a ten-year love affair. Both seem to have considered marriage solely because of social conventions or out of financial necessity. Though a Northerner, Brown's economic situation was more complicated than white women's. At first, she had misgivings about having both a female lover and a male suitor and viewed her love for Primus as incompatible with marriage to a man. On 21 September 1862, when Mr. Lee was courting her, she wrote to Primus: "I often told you there is no one I love as I do you, not even the man I expect in the future to call husband." (Griffin 70, emphasis mine). As Sarah Jasmin Griffin indicates, finally accepting economic and social expectations, she later came to view the institution as necessary to her economic survival (Griffin 236). At the early stages of their 
relationship, she informed Primus that she had warned her suitor that she cared more for her than she did for him and told "him [that she] did love [Rebecca] more th[a]n [she] ever would him" (Griffin 85). Lee renounced courting her after that. She later flirted with Nelson, Primus's brother, which damaged their relationship (Griffin 70), and, in April 1868, married Joseph Tines, a domestic worker, for whom she had affection. Primus also contemplated marriage, though later than Brown, probably due to her more affluent background, and married Charles Thomas, a previously married southern-born black man who had purchased his freedom (Griffin 77) that she had met in Royal Oak, Maryland (Griffin 281). After they moved to Connecticut he worked as a janitor and gardener (Griffin 281-282) and they lived happily until his death in 1891, when Rebecca went to live with her mother.

61 These women's views on motherhood were just as influenced by their economic and social backgrounds, and upbringing. For instance, Harris wished to have children and was expecting her first baby soon after her marriage. Primus apparently seems to have only had one child: while the editor of the letters was "unable to find records of such a birth", one person who had known Primus "said that she saw a picture in Rebecca's room of a son who had died many years earlier" (Griffin 284). Yet some black women had conflicting feelings toward motherhood because of their personal experience of white male sexual domination under slavery. For example, Keckley explains that she deeply loved her son though he was the product of her rape by her former owner, but she initially did not wish to have children in bondage. Later, as a free woman, she never had other children (Keckley 39). Family circumstances could temporarily deter some women from having children. Wells did not have a strong desire for children when she got married (Wells, 1970 251). She had in fact satisfied her maternal wishes when she raised her siblings at the age of 14 . She later wrote in her autobiography: "somehow I felt entitled to the vacation from my days as nurse after that time" (Wells, 1970 251). This was not definite though: she later had four children and raised two children from her husband's first marriage. How did middle-class women such as Wells manage to combine their roles as mothers and as professional workers?

Between the mid-1860s and the early 1910s, middle- and upper-class women of color still combined several roles: worker, housewife, and, in many cases, mother. This had always been encouraged: married African American women had very often worked since the antebellum period. Their ideal of womanhood required involvement in the public sphere (Howard 69). Although working outside of home was common, very few unmarried upper- or upper-middle-class black women such as Wells could imagine pursuing a career then. Public work included teaching, doing local church work, delivering speeches or writing newspaper articles. Black organizations such as the National Association for the Advancement of Colored People (NAACP), founded in 1909 or the Niagara movement founded by Du Bois in 1905 encouraged the participation of women like Wells or Mary White Ovington, a white journalist and suffragist. In that sense, Wells is an exception in this sample. Yet, women who pursued careers as educators often stopped working after their marriage, sometimes due to state legislations. For example, after marrying, Primus is listed in the 1870 census as "at home" (Griffin 281). Only later did working while being married become more socially accepted (Gilmore 43).

63 At the turn of the twentieth century, a new role for women emerged. The "new woman" was middle- or upper-class, free, modern, independent, active, and slim. 
Rejecting corsets, she wore her hair short, attended college, and could reject marriage. This figure was popularized through the Gibson girl, drawn by the artist Charles Dana Gibson (Patterson 2008a; Patterson 2008b). Yet, many women outside this social class, such as the anonymous child-nurse, still entered matrimony ("'More Slavery at the South"' 196).

On the contrary, middle- and upper-class women of the late nineteenth century often wished to retain part of their identity, by choosing to marry late-if at all-and by limiting and/or scheduling their pregnancies (Davis 145). This was the case of several leading clubwomen and race leaders such as Ida B. Wells and Mary Church Terrell. Others like Fannie Barrier Williams and Anna Julia Cooper did not have children (Carby, 1986 315). Explicit references to contraception methods in African American women's writings however remain rare.

Many married middle-class women, regardless of race, also kept their maiden names, a sign of independence. For instance, when Wells married Ferdinand Lee Barnett in 1895, she had her last name hyphenated. In fact, according to Carlson, "some notable black women were better known than their husbands": Ida B. Wells-Barnett, for instance, would become "more famous than her husband Ferdinand Barnett" (Carlson 67).

Moreover, importantly, bourgeois women also tended to view marriage as a partnership. For example, Ferdinand Barnett willingly took care of the cooking and hired help to do the cleaning while working as a lawyer and Ida B. Wells-Barnett devoted her energy to her children until they were seven and then pursued her career as a writer and activist. This compromise enabled both to satisfy their needs and carry out their goals (Wells, 1995 194; Gilmore 18).

At the turn of the twentieth century, motherhood remained important in the lives of women of color, regardless of their social class. In the South, where most African Americans still lived in the 1890s and where educational opportunities for blacks were poorer, most African American women, with little or no education, few skills besides farming or cooking, and no financial means to leave the South, still had no alternative to being domestics or child-nurses for white families. Discrimination on the workplace further deteriorated black women's relationship with their offspring due to abusive contract clauses. Salaries were dramatically low compared to other occupations and remained so well into the twentieth century. For example, comparing her condition in the 1910s and the slavery era, the anonymous child-nurse writes: "You might as well say that I'm on duty all the time-from sunrise to sunrise, every day in the week. I am the slave, body and soul, of this family. And what do I get for this work-this lifetime of bondage? The pitiful sum of ten dollars a month!" (emphasis mine). Moreover, the tasks she accomplished often went beyond her regular attributions:

I not only have to nurse a little white child, now eleven months old, but I have to act as playmate, or "handy-andy," not to say governess, to three other children in the house, the oldest of whom is only nine years of age [...] So it is not strange to see "Mammy" watering the lawn with the garden hose, sweeping the sidewalk, mopping the porch and halls, helping the cook, or darning stockings. Not only so, but I have to put the other three children to bed each night as well as the baby, and I have to wash them and dress them each morning. [...] I see my own children only when they happen to see me on the streets when I am out with the children, or when my children come to the "yard" to see me, which isn't often, because my white folks don't like to see their servants' children hanging around their premises. (“"More Slavery at the South"' 196) 
Women like the anonymous child-nurse often felt that they sacrificed their roles as mothers to their own children in order to earn a salary, working harder at raising white children to the detriment of their own offspring. The contracts often stipulated that child-nurses were to stay home with the family six days a week. In 1912, the childnurse indicated that on top of working "fourteen to sixteen hours a day," she was "compelled to, by [her] contract, which is oral only, to sleep in the house" and was "allowed to go home to [her] own children, the oldest of whom is a girl of 18 years, only once in two weeks, every other Sunday afternoon-even then [she was] not permitted to stay all night" (“"More Slavery at the South"' 196). Similar conditions existed in the North, where employers also demanded long hours for a meager salary (Davis 67).

Not all women of the South experienced motherhood this way. Harris, for instance, had nine children between 1884 and 1905, seven of whom survived to adulthood. In her writings, she delighted in her children's achievements and seems to have enjoyed her role as a mother tremendously. Class played a determining factor in African American women's enjoyment of motherhood. Yet region was an important factor as well, since northern middle-class black mothers sometimes met less difficulty, mainly because, in addition to being able to rely on relatives-mothers, aunts, cousins-or friends, for the care of their children, just like black Southerners, they could sometimes find assistance in settlement houses or kindergartens run by local clubwomen like Victoria Earle Matthews in New York City in the 1890s and Jane Edna Harris Hunter in Cleveland in the 1910s (Hunter).

Economic privilege allowed bourgeois mothers to devote themselves more fully to their children. For example, when Wells became a mother in 1896, she slowed down the pace of her activities. With the birth of her second son in 1897, she "retired to the privacy of [her] home to give [her] attention to the training of [her] children" (Wells, 1970 250, xxiii). Wells felt that, after the birth of her first children, "if the mother does not have the training and control of her child's early and most plastic years, she will never gain that control" (Wells, 1970 250). To her, the presence of a mother was paramount, especially until the age of seven. Importantly, she praised the women's alleged natural role as mothers:

I had become a mother before I realized what a wonderful place in the scheme of things the Creator has given woman. It is she upon whom rests the joint share of the work of creation, and I wonder if women who shirk their duties in that respect truly realize that they have not only deprived humanity of their contribution to perpetuity, but that they have robbed themselves of one of the most glorious advantages in the development of their own womanhood. I cannot begin to express how I reveled in having made this wonderful discovery for myself or how glad I was that I had not been swayed by advice given me on the night of my marriage which had for its object to teach me how to keep from having a baby. (Wells, 1970 251-252, emphasis mine)

It is difficult to know who provided her with this advice, but she did not follow it and gave birth to her first child in 1896 , at the age of 34 , that is, only one year after her wedding-becoming a mother at 34 was considered late. After the birth of her other children in 1897, 1901, and 1904, she returned to political activism progressively as she felt compelled to act for the race. In 1898, she focused on lynching: "even though I was quite content to be left within the four walls of my home, it seems that the needs of the work were so great that again I had to venture forth" (252); later, "despite my best intentions, when I got back home to my family, I was again launched in public movements" (256). Of course, other women suspected that she had issues taking on 
what Susan B. Anthony termed the "divided duty" of being both an activist and a mother (255). Like other women from more modest milieus, Wells resorted to family aid: her second baby was nursed by his grandmother once weaned $(255,270)$. Yet, in order to juggle work and family, Wells could also count on the help of a hired domestic, allowing her to focus on child-raising and activist work (Wells, 1995 194). Thus, not only region, but also social class were the main determining factors that made life experiences different for women.

70 In the early twentieth century, the situation only slightly evolved, even though more and more middle-class married women could have a career. Only middle- and upperclass women who married late or controlled their fertility were able to pursue a career. Between 1865 and 1900, at the time when educational prospects grew higher for African American women, the proportion of women who rejected marriage rose: W.E.B. Du Bois's 1900 study of the black college graduates indicates that only " $50 \%$ of the black women college graduates from 1860-1899 were married" (Du Bois, 1900 55, quoted in Perkins, 1983 185). Many were Southerners who graduated from HBCUs such as Spelman College, Fisk University, Claflin University, or Hampton University; far fewer came from the North or West who attended HBCUs such as the Institute for Colored Youth in Pennsylvania, now called Cheney University, or institutions which accepted students of color, such as Oberlin College (Du Bois and Granville Dill 46-47). In fact, contrary to white women, "black women did not usually have to choose between higher education and marriage or between teaching and marrying" (Gilmore 43). In fact, some of them kept teaching and wedded school principals, thus forming a team of educators. Shirley Carlson also claims that for upper-class women in 1880s and 1890s Illinois, marriage was compatible with domestic achievements (Carlson 62). Yet this does not mean that these women renounced or were less eager to experience motherhood, which remained an important aspect of society's definition of womanhood. In both periods, black women's experience of motherhood was affected by both racial and economic subjugation, but also by their relationship with their spouses.

\section{Conclusion}

71 Although African American women were often raised in conservative ways and, when possible, in keeping with Victorian ideals, many of their written testimonies stress the need for self-reliance and independence as a way to counteract their lack of political and economic power and the institutional racism and sexism of their times. After emancipation in 1865 , they continued to display agency. Black women kept working outside the home and continued their struggle for dignity, while developing strategies to enhance their protection through education and community work.

Thanks to these letters, diaries, and autobiographies, the reader is not only able to understand how they viewed work life, men, love, and marriage, but also how they construed womanhood and motherhood. This analysis has revealed that these women believed in self-help and resorted to their own energy to better their situations. They considered it their duty to prove that, through fighting against discrimination and injustice, they had an essential role to play in their community and country. Each woman in this study developed strategies of self-help, race uplift, and community work. 
73 As the century drew to an end, black and white American women had to find solutions to cope with growing sexism and black women neither completely contradicted Victorianism nor fully espoused it: they continued to shape their own definition of womanhood. Constrained in their efforts by racism and sexism, most African American women had to openly challenge the social codes of Victorianism. Several women in this study adopted what Carlson termed a "dual womanhood". Most rejected notions of domesticity and submissiveness, either because they chose to or because they were compelled to by their economic circumstances. These women-some of whom conformed to the image of the "lady"-artfully managed to combine drastically opposed qualities. Indeed, African American women of the elite-such as Anna Julia Cooper, Ida B. Wells-Barnett, Josephine St. Pierre Ruffin, Fannie Barrier Williams, or Mary Church Terrell-adopted a rhetoric that aimed at defending black womanhood and showing its strength and centrality in the struggle for the advancement of the "race" (Carby, 1987 6, 32; White and Dobris). Their struggle and the definition they gave to womanhood in the nineteenth and early twentieth century dramatically influenced American womanhood.

\section{BIBLIOGRAPHY}

\section{Primary sources}

ALEXANDER, William T. History of the Colored Race in America. New Orleans, 1888.

DU BOIS, W.E.B., ed. The College-bred Negro: Report of a Social Study Made Under the Direction of Atlanta University; together with the Proceedings of the Fifth Conference for the Study of the Negro Problems, Held at Atlanta University, May 29-30, 1900. Atlanta, Georgia: Atlanta University Press, 1900.

---. Black Reconstruction in America. 1900. Piscataway: Transaction Publishers, 2013.

DU BOIS, W.E.B., and Augustus GRANVILLE DILL, eds. The College-bred Negro American: Report of a Social Study made by Atlanta University under the patronage of the Trustees of the John F. Slater Fund; with the Proceedings of the 15 th Annual Conference for the Study of the Negro Problems, held at Atlanta University, on Tuesday, May 24 $4^{\text {th }}$, 1910. Atlanta: Atlanta University Press, 1910.

GRIFFIN, Farah Jasmine, ed. Beloved Sisters and Loving Friends: Letters from Rebecca Primus of Royal Oak, Maryland and Addie Brown of Hartford, Connecticut, 1854-1868. New York: Knopf, 1999.

HACKLEY, E. Azalia. The Colored Girl Beautiful. Kansas City: Burton Publishing, 1916. Available at https://archive.org/details/coloredgirlbeaut0ohack. Accessed March 26, 2019.

HARRIS, Elizabeth Johnson. Life Story, 1867-1923. On-line Archival Collection, Special Collections Library at Duke University. library.duke.edu/rubenstein/scriptorium/harris/harris-indx.html. Accessed September 16, 2010.

HUNTER, Jane Edna Harris. A Nickel and A Prayer. 1940. Morgantown: West University Press, 2011. 
KECKLEY, Elizabeth. Behind the Scenes, or, Thirty Years a Slave, and Four Years in the White House. 1868. Call number CB K25B, North Carolina Collection, University of North Carolina at Chapel Hill. online edition 1999. docsouth.unc.edu/neh/keckley/keckley.html. Accessed May 24, 2014.

MONTGOMERY, Mary Virginia. Diary (microfilm). Davis Library, University of North Carolina at Chapel Hill. Call number 1-5789. Available in: We Are Your Sisters: Black Women in the Nineteenth Century. Ed. Dorothy Sterling. New York: Norton, 1984, p. 462-472.

“"More Slavery at the South,' by a Negro Nurse". The Independent. New York: published for the proprietors, 1848-1921, vol. 72, January 25, 1912, p. 196-200. docsouth.unc.edu/fpn/negnurse/ negnurse.html. Accessed March 26, 2019.

STERLING, Dorothy. We Are Your Sisters: Black Women in the Nineteenth Century. New York: Norton, 1984.

WELLS, Ida B. Crusade for Justice: The Autobiography of Ida B. Wells. Ed. Alfreda Duster. Chicago: University of Chicago Press, 1970.

---. The Memphis Diary of Ida B. Wells: An Intimate Portrait of the Activist as a Young Woman. Ed. Miriam DeCosta-Willis. Boston: Beacon Press, 1995.

\section{Secondary sources}

BOGGLE, Donald. Toms, Coons, Mulattoes, Mammies and Bucks: An Interpretive History of Blacks in American Films. New York: Continuum, 1994.

BUTCHART, Ronald. Schooling the Freedpeople: Teaching, Learning, and the Struggle for Black Freedom, 1861-1876. Chapel Hill: University of North Carolina Press, 2010.

CARBY, Hazel V. "On the Threshold of Woman's Era: Lynching, Empire, and Sexuality in Black Feminist Theory." "Race," Writing, and Difference. Ed. Henry Louis Gates. Chicago: University of Chicago Press, 1986, p. 301-316.

---. Reconstructing Womanhood: The Emergence of the Afro-American Woman Novelist. Oxford: Oxford University Press, 1987.

CARLSON, Shirley. "Black Ideals of Womanhood in the Late Victorian Era." Journal of Negro History, vol. 77, no. 2, 1992, p. 61-73.

COTT, Nancy. The Bonds of Womanhood: “Woman's Sphere" in New England, 1780-1835. New Haven: Yale University Press, 1977.

COX, Karen L. Dreaming of Dixie: How the South was Created in American Popular Culture. Chapel Hill: University of North Carolina Press, 2011.

CULLEY, Margo. A Day at a Time: The Diary Literature of American Women from 1764 to the Present. New York: Feminist Press, 1985.

DAVIS, Angela. Femmes, race et classe. 1983. Translated from the American by Dominique Taffin. Paris: Des Femmes, Antoinette Fouque, 2013.

DIDIER, Béatrice. Le journal intime. Paris: Presses Universitaires de France, 2002.

EVANS, Sara M. Born for Liberty: A History of Women in America. New York: Free Press, 1989.

FAULKNER, Carol. Women's Radical Reconstruction: The Freedmen's Aid Movement. Philadelphia: University of Pennsylvania Press, 2004.

FONER, Eric. Give me Liberty! An American History. New York: Norton, 2012. 
GIDDINGS, Paula. When and Where I Enter: The Impact of Black Women on Race and Sex in America. New York: Quill/W. Morrow, 1984.

GILMORE, Glenda. Gender and Jim Crow: Women and the Politics of White Supremacy in North Carolina, 1896- 1920. Chapel Hill: University of North Carolina Press, 1996.

GUTERL, Matthew. The Color of Race in America, 1900-1940. London: Harvard University Press, 2001.

HARRISON, Kimberly. "Rhetorical Rehearsals: The Construction of Ethos in Confederate Women's Civil War Diaries.” Rhetoric Review, vol. 22, no. 3, 2003, p. 243-263.

HINE, Darlene Clark, John MCCLUSKEY Jr., and David Barrar JASPAR, eds. Hine Sight: Black Women and the Reconstruction of American History. Brooklyn: Carlson Publishing, 1994.

HIGGINBOTHAM, Evelyn Brooks. Righteous Discontent: The Women's Movement in the Black Baptist Church, 1880-1920. Cambridge, MA: Harvard University Press, 1993.

HOWARD, Vicki. "The Courtship Letters of an African American Couple: Race, Gender, Class and the Cult of True Womanhood." A Question of Manhood: A Reader in US Black Men's History and Masculinity, Volume 2: The 19 $9^{\text {th }}$ century: From Emancipation to Jim Crow. Eds. Ernestine Jenkins and Darlene Clark Hine. Bloomington: Indiana University Press, 2001, p. 234-248.

KAISER-FARMER, Mary. Freedwomen and the Freedmen's Bureau: Race, Gender and Public Policy in the Age of Emancipation. New York: Fordham University Press, 2010.

LADNER, Joyce. "Racism and Tradition: Black Womanhood in Historical Perspective." The Black Woman Cross-Culturally. Ed. Filomino Chioma Steady. Cambridge, MA: Schenkman Publishing, 1981, p. 269-288.

LEJEUNE, Philippe. Le pacte autobiographique. Paris: Seuil, 1975.

MCCURRY, Linda O. To Keep the Waters Troubled: The Life of Ida B. Wells. New York: Oxford University Press, 1998.

MCPHERSON, James M. The Abolitionist Legacy, From Reconstruction to the NAACP. Princeton: Princeton University Press, 1976.

MIRAUX, Jean-Philippe. L'Autobiographie: écriture de soi et sincérité. Paris: Armand Colin, 2009.

PATTERSON, Martha H. Beyond the Gibson Girl: Reimagining the American New Woman, 1895-1915. Urbana: University of Illinois, 2008.

---. The American New Woman Revisited: A Reader, 1894-1930. New Brunswick: Rutgers University Press, 2008.

PERKINS, Linda M. “'The Impact of the Cult of True Womanhood' on the Education of Black Women." The History of Higher Education. Eds. L.G. Goodchild and H. S. Wechsler. Boston: Pearson Custom Publishing, 1983, p. 183-190.

---. "Black Women and Racial Uplift Prior to Emancipation." The Black Woman Cross-Culturally. Ed.Filomino Chioma Steady. Cambridge, MA: Schenkman Publishing, 1981, p. 317-334.

SCOTT, Anne Firor. The Southern Lady, From Pedestal to Politics: 1830-1930. Chicago: University of Chicago Press, 1970.

SHAW, Stephanie. What a Woman ought to Be and Do: Black Professional Women Workers During the Jim Crow Era. Chicago: University of Chicago Press, 1996.

SILBER, Nina. “'A Woman's War': Gender and the Civil War Studies.” OAH: Magazine of History, vol. 8, no. 1, 1993, p. 11-13. 
STAUFFER, John. The Black Hearts of Men: Radical Abolitionists and the Transformation of Race.

Cambridge, MA: Harvard University Press, 2002.

WALLACH, Jennifer. Closer to the Truth than any Fact: Memoir, Memory and Jim Crow. Athens:

University of Georgia Press, 2008.

WELTER, Barbara. “The Cult of True Womanhood: 1820-1860." American Quarterly, vol. 18, no. 2, 1966, p. 151-174.

WHITE, Cindy L., and Catherine A. DOBRIS. "The Nobility of Womanhood: 'Womanhood' in the Rhetoric of $19^{\text {th }}$ Century Black Clubwomen." Centering Ourselves: African American Feminist and Womanist Studies of Discourse. Eds. Marsha Houston and Olga Idriss Davis. Cresskill: Hampton Press, 2002, p. 171-185.

WOLCOTT, Victoria W. Remaking Respectability: African American Women in Interwar Detroit. Chapel Hill: University of North Carolina Press, 2001.

\section{NOTES}

1. "Victorianism" may be defined as a period of profound economic, technological and societal changes due to the Industrial Revolution in Britain during the reign of Queen Victoria (1837-1901). In the United States as in Britain, the theory of the separate spheres and the cult of True Womanhood also developed. Victorianism includes a middle-class component. From 1820 until the beginning of the Civil War, middle-class American women were expected to abide by certain rules-e.g. remain in the domestic sphere-and possess certain "feminine" qualities (Cott). According to Barbara Welter, the four pillars of true womanhood were: piety, purity, domesticity and submissiveness. Victorian women were expected to behave as "ladies." Moreover, before and after the Civil War, Victorianism was particularly conservative in the South (Scott), making it particularly difficult for middle- and upper-class black women to carve their place in this worldview (Wolcott).

2. A renowned institution in Ohio, Oberlin College was founded in 1833 by Presbyterian Ministers who had an inclusive vision of education. In 1835, Oberlin was the first College to admit black students. Very little information is available about Montgomery's teaching experience. It appears that in 1895, she was appointed postmistress of Mount Bayou, near Davis Bend, where her family bought some land after the war.

3. Wells's decision to become a journalist was particularly bold since she exposed herself to danger. By voicing her opposition to lynching, she was the target of threats and attacks against her person. For instance, in 1892, when she published an article to denounce the lynching of Thomas Moss in Memphis, the newspaper she was working for, The Free Speech, was destroyed and her life was threatened. She had to flee the South and stayed in exile for the rest of her life. Despite her efforts, her fight against lynching proved unsuccessful and racial violence continued for decades.

4. Her autobiography was edited and published in 1970 by her daughter Alfreda Duster. Aware of being an important figure of the fight for black civil rights, Wells-Barnett probably intended to chronicle her anti-lynching crusade and women's rights struggle for posterity. She was also a particularly active citizen, having run as an Independent for the 1930 State Senate elections shortly before she wrote her life story.

5. Owning land enabled the Johnson family to be financially independent, which was quite exceptional at that time: contrary to many other black families, they were not sharecroppers. Unlike several women in this study, Johnson did not intend to leave her family or the South as a young girl. Her 85-page memoir was given to the David M. Rubenstein Rare Books and 
Manuscript Library at Duke University in 1984 by Mayme Perry, one of Harris' descendants. It is digitized and accessible online. It is unclear why she penned her life story, beyond her being a poet and her general inclination to write.

6. During Reconstruction, both black and white women who aspired to be part of the moral and social uplift of freedpeople could enroll as teachers, go south and gain emotional and financial independence for themselves at the same time (Faulkner; Butchart).

7. Harris did go north several times to visit her children. Brown traveled only temporarily to New York City in 1861-1862.

8. Sojourner Truth, who positioned herself against certain norms imposed by the cult of True Womanhood, is particularly well known for her words “Ain't I a woman?", pronounced in 1851 at the Women's Convention in Akron, Ohio.

9. Though a black equivalent of the white American lady, Carlson considered this figure to be out of step with white norms of true womanhood.

\section{ABSTRACTS}

This article shows the diversity of African American women's life experiences through the study of the life narratives of seven women who belonged to different social milieus, had distinct regional identities and dissimilar occupations. Drawing on their correspondence, diaries, and autobiographies, this article explores these women's economic circumstances, their views on men, marriage, their roles as women, wives, and mothers, and the condition of being a woman of color between 1861 and the late 1910s-a period of dramatic change in the history of the United States, particularly regarding the question of women's rights. Covering the Civil War, Reconstruction, the Progressive Era, and up to the beginning of World War I, this work examines the way these women expressed their self-identities.

Cet article montre la diversité des expériences de vie d'Africaines-Américaines à travers l'étude des récits de vie de sept femmes venues d'horizons différents-appartenant à diverses classes sociales, ayant des identités régionales distinctes et occupant des emplois divers. S'appuyant sur leurs lettres, journaux intimes ainsi que sur leurs autobiographies, cet article analyse le regard que ces femmes portaient sur leur situation, leur rôle de femmes, d'épouses et de mères ainsi que la condition des femmes de couleur entre 1861 et la fin des années 1910-période de grands bouleversements dans l'histoire américaine, notamment en ce qui concerne la question du droit des femmes. Ce travail, qui couvre les périodes de la guerre de Sécession, la Reconstruction et la période progressiste, examine la façon dont ces femmes envisageaient leur identité.

\section{INDEX}

Keywords: African-American women, identity, African-American history, life narratives, autobiographies, diaries, women's correspondence, African American lesbian correspondence Mots-clés: femmes africaines-américaines, identité féminine, histoire africaine-américaine, récits de vie, autobiographies, journaux intimes, correspondance féminine, correspondance de femmes africaines-américaines lesbiennes 
AUTHOR

ÉLISE VALLIER

Université Paris-Est-Marne-La-Vallée 